\title{
PERKEMBANGAN STRUCTURAL EQUATION MODELING (SEM) DAN APLIKASINYA DALAM BIDANG EKONOMI
}

\author{
Sayyida ${ }^{1}$ \\ Alwiyah $^{2}$ \\ ${ }^{1}$ Program studi manajemen, FEB,Universitas Wiraraja \\ sayyida@wiraraja.ac.id \\ ${ }^{2}$ Program studi Akuntansi, FEB,Universitas Wiraraja \\ alwiyahmahdaly@wiraraja.ac.id
}

\begin{abstract}
Economic phenomenon Area is complicated to be researched. Many research which is difficult to be finished by ordinary analysis. So that in the year 1916, Swall Wright introduce analyzer of Structural Equation Modelling (SEM). Until this time SEM is popular among social research of do not aside in economic area. Have many success economics research finish economic phenomenon with structure SEM analyse which complicated. Structure in SEM which is complicated oblige all consumer to be more take a care in using it in order not to happened mistake of interpretation particularly again mistake of usage. This article aim to give the understanding of hitting SEM and its growth and also its application specially to researcher in economic area. This article present the understanding of hitting SEM started from estimation method, software which can wear, way of activity, weakness and advantage and also various application of SEM in economic area specially.
\end{abstract}

Keywords : Structural Equation Modelling (SEM), research method, economic.

Latar Belakang

Structural Equation Modeling

(SEM) merupakan alat analisis statistika yang banyak digunakan di berbagai bidang ilmu pengetahuan tidak terkecuali dalam ilmu ekonomi. Karya Swall Wright pada tahun 1916 merupakan awal mula munculnya SEM dan mulai berkembang sekitar tahun 1970an (Golob, 2001; Shah \& Goldstein, 2006). Menurut Awang (2014) dalam bukunya yang berjudul $A$ Handbook on SEM for Academicians and practitioners mengatakan bahwa SEM merupakan generasi kedua dari teknik analisis multivariat yang dibangun karena adanya keterbatasan teknik klasik yaitu Ordinary Least Square (OLS) khususnya dalam melakukan analisis dengan variabel laten dan model-model yang kompleks. SEM merupakan teknik analisis statistik untuk mengestimasi serta mengevaluasi model yang terdiri dari hubungan linier antara variabel yang biasanya sebagian besar merupakan variabel yang tidak dapat diamati secara langsung (Adedeji, Sidique, Rahman, \& Law, 2016). Variabel yang tidak dapat diamati secara langsung biasanya disebut sebagai variabel laten sedangkan variabel yang bisa diamati secara langsung disebut 


\section{FAKULTAS EKONOMI DAN BISNIS UNIVERSITAS WIRARAJA - MADURA}

variabel manifest. Pengukuran variabel laten didasarkan pada beberapa variabel manivest yang berfungsi sebagai indikator untuk varibel laten (Shah \& Goldstein, 2006). SEM merupakan metode populer dalam ilmu sosial yang memungkinkan peneliti untuk mengaitkan variabel satu dengan lainnya secara fleksibel sesuai teori yang kemudian diuji terhadap data sampelnya (Alshetewi \& Karim, 2015). Artikel ini bertujuan untuk memberikan pemahaman mengenai SEM dan perkembangannya serta aplikasinya khususnya dibidang ekonomi. Dengan adanya artikel ini diharapkan peneliti pemula tidak canggung atau salah dalam menggunakan SEM sebagai alat analisis dalam penelitiannya.

\section{Metode Estimasi dan Software}

SEM merupakan alat analisis yang mengkombinasikan berbagai alat statistik, seperti analisis faktor, regresi, dan M(ANOVA) (Nachtigall, Kroehne, Funke, \& Steyer, 2003). SEM bertujuan untuk mengkonfirmasi apakah model yang telah hipotesisnya valid atau tidak bukan untuk menemukan model, sehingga pengguna diharuskan membuat model berdasarkan teori yang ada (Golob, 2001; Shah \& Goldstein, 2006). Menurut (Shah \& Goldstein, 2006), SEM merupakan bagian dari covariance structure modeling (CSM). CSM merupakan model umum mengandung model time series yaitu ARMA, model multiplikatif, model data multi-faced dan circumplex model seperti SEM. SEM merupakan gabungan analisis path dan confirmatory factor analysis (CFA) sebagaimana gambar 1 berikut. Gambar 1 menunjukkan hubungan SEM, analisis Path dan Confirmatory Factor Analysis (CFA). Analisis path untuk menentukan pola hubungan antara variabel manivest. Sedangkan CFA untuk mengkonfirmasi hubungan antara variabel manivest dan variabel latennya serta untuk menunjukkan variabel laten mana yang memungkinkan untuk dikorelasikan. CFA bertujuan untuk menguji measurement model dan validasi penelitian sedangkan analisis path untuk menguji model variabel laten. Sehingga SEM dapat menguji keduanya yaitu model pengukuran dan model struktural.

Sebuah SEM dengan variabel laten terdiri dari tiga set persamaan simultan, yang diperkirakan secara bersamaan: (1) model pengukuran (atau submodel) untuk variabel endogen (dependen), (2) model pengukuran (sub) untuk eksogen ( independen), dan (3) model struktural (sub), yang semuanya diperkirakan bersamaan. Model struktural SEM digunakan untuk menangkap pengaruh kausal (efek regresi) dari variabel eksogen pada variabel endogen dan pengaruh kausal 
dari variabel endogen satu sama lain.

Model pengukuran SEM digunakan

untuk menentukan variabel laten (tidak teramati) sebagai fungsi linier (weighted averages) dari variabel lain dalam sistem. Ketika variabel-variabel lain ini diamati, mereka mengambil peran "indikator" konstruksi laten. Dengan cara ini, model pengukuran SEM serupa dengan analisis faktor. SEM didasarkan pada tiga perkembangan analisis utama: analisis jalur, pemodelan variabel laten, dan metode estimasi kovarian umum. Tiga konsep analisis jalur yaitu persamaan struktur kovariansi pertama, jalur diagram atau grafik kausal, dan dekomposisi efek total antara keduanya variabel menjadi total, efek langsung dan tidak langsung (Golob, 2001).

\section{Gambar 1.}

SEM, analisis Path dan CFA

(a) Structural Equation Modeling Model

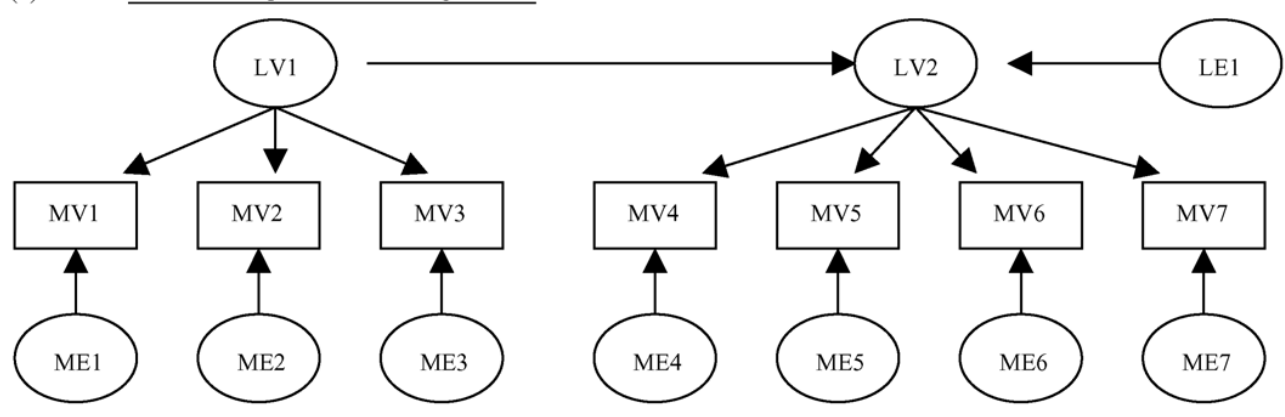

(b) Path Analysis Model

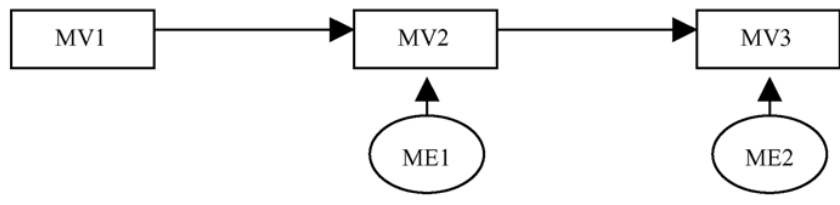

(c) Confirmatory Factor Analysis Model

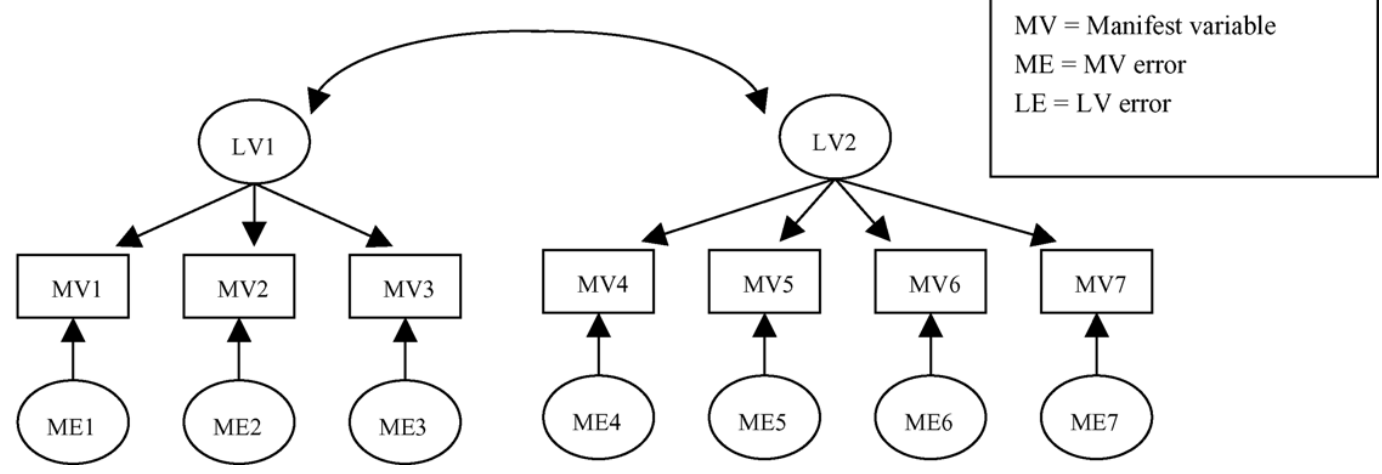

Sumber : (Shah \& Goldstein, 2006) 


\section{FAKULTAS EKONOMI DAN BISNIS UNIVERSITAS WIRARAJA SUMENEP - MADURA}

Metode estimasi SEM yang paling umum digunakan adalah: teori normal maximum likelihood (ML), general least least square (GLS), kuadrat terkecil tertimbang (WLS), dalam bentuk seperti distribusi berdimensi asimtotik bebas kuadrat terkecil (ADF atau ADF-WLS), dan kuadrat terkecil belakang elips (EGLS atau ELS) (Golob, 2001). Dalam melakukan estimasi, kebanyakan software yang ada menggunakan metode Maksimum Likelihood (ML), dengan asumsi normal secara multivariat dan memliki ukuran sampel yang cukup besar. Uji kecocokan model dalam SEM adalah mengkonfirmasi model dengan data empiris. Dengan SEM, penelitian dapat mengetahui efek langsung, sefek tidak langsung serta efek total. Istilah efek ini bukanlah menunjukkan model kausal, karena model SEM tidak didasarkan pada model kausalitas melainkan didasarkan pada korelasi. (Golob, 2001; Nachtigall et al., 2003). Untuk mendapatkan estimasi yang akurat, SEM membutuhkan lebih dari 200 sampel . Uji kesesuaian model menggunakan ambang batas Chi-square > 0,05, Comparison of fit Index $(\mathrm{CFI})>0,09$ dan Root Mean Square Errorof Epproximation (RMSEA) $<0,05$ (Kusurkar, Vos, Westers, \& Croiset, 2013)
Dalam melakukan perhitungan untuk kepentingan analisis, banyak software yang dapat dipakai diantaranya AMOS, LISREL, EQS, Mplus, SmartPLS dan lain-lain. Dengan berjalannya waktu, software-software tersebut semakin berkembang disesuaikan dengan kebutuhan analisis dan kondisi data saat ini (Nachtigall et al., 2003; Ramli, Akasah, \& Masirin, 2014).

\section{Cara Kerja}

Cara kerja SEM diawali dengan teori untuk membangun model yang akan dihipotesiskan. Kerangka pikir digambarkan dalam sebuah diagram yang menghubungkan antar variabel baik variabel laten maupun variabel manifest. Variabel laten biasanya diukur menggunakan kuisioner. Idealnya, kuisioner menggunakan skala pengukuran interval 1 sampai 10 agar memenuhi persyaratan analisis parametrik. Sebaiknya paling sedikit 4 item pengukuran untuk masing-masing konstruk laten (Awang, 2014). Uji mesurement model dengan mengaitkan hubungan 2 arah untuk semua variabel laten seperti contoh yang ditunjukkan pada gambar 2. Sedangkan uji struktur model digambarkan dengan pola hubungan sebagaimana yang dihipotesiskan seperti contoh gambar 3 (Adedeji et al., 2016). 
Gambar 2.

Diagram measurement model

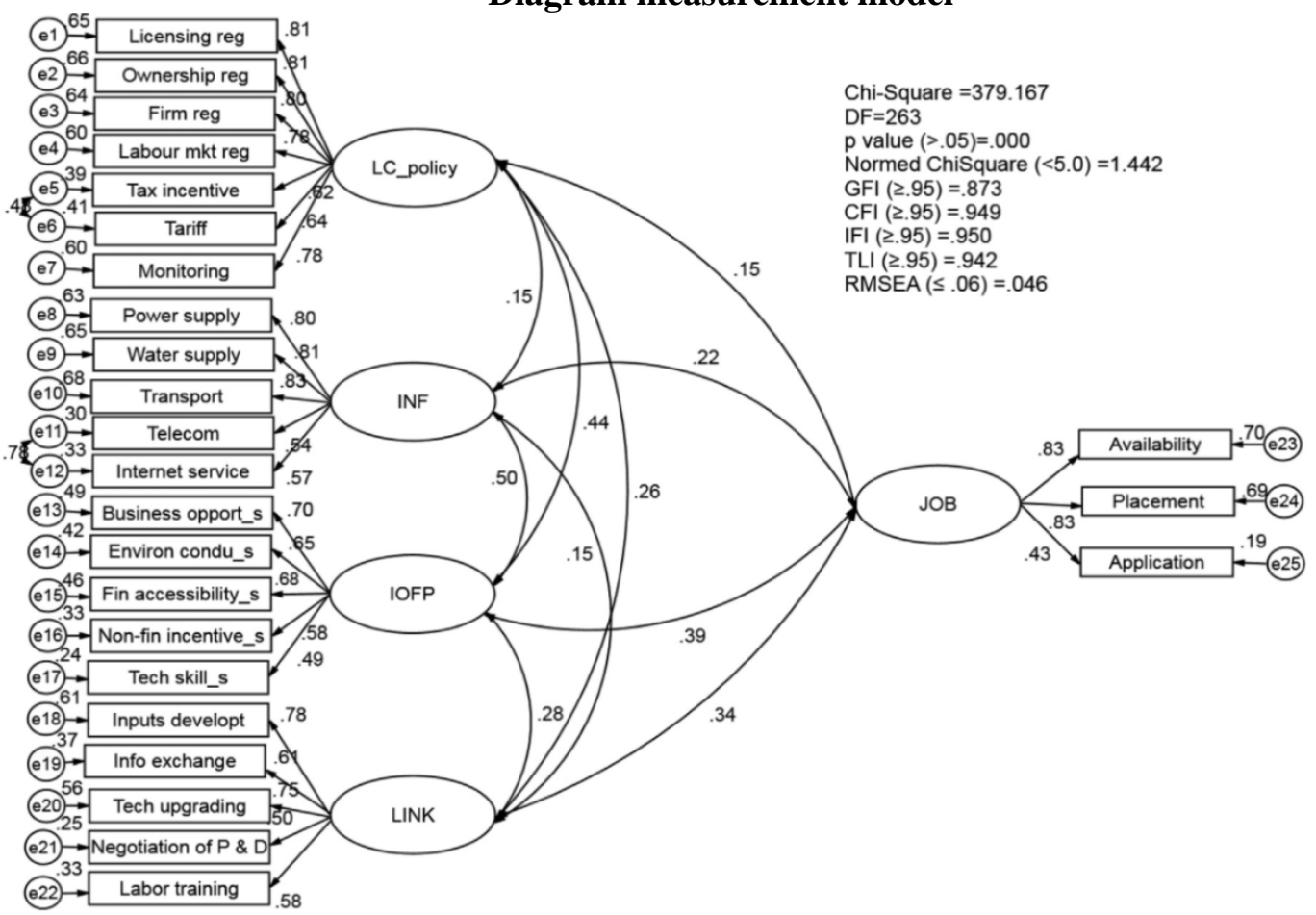

Sumber : (Adedeji et al., 2016)

Gambar 3.

Diagram struktural model

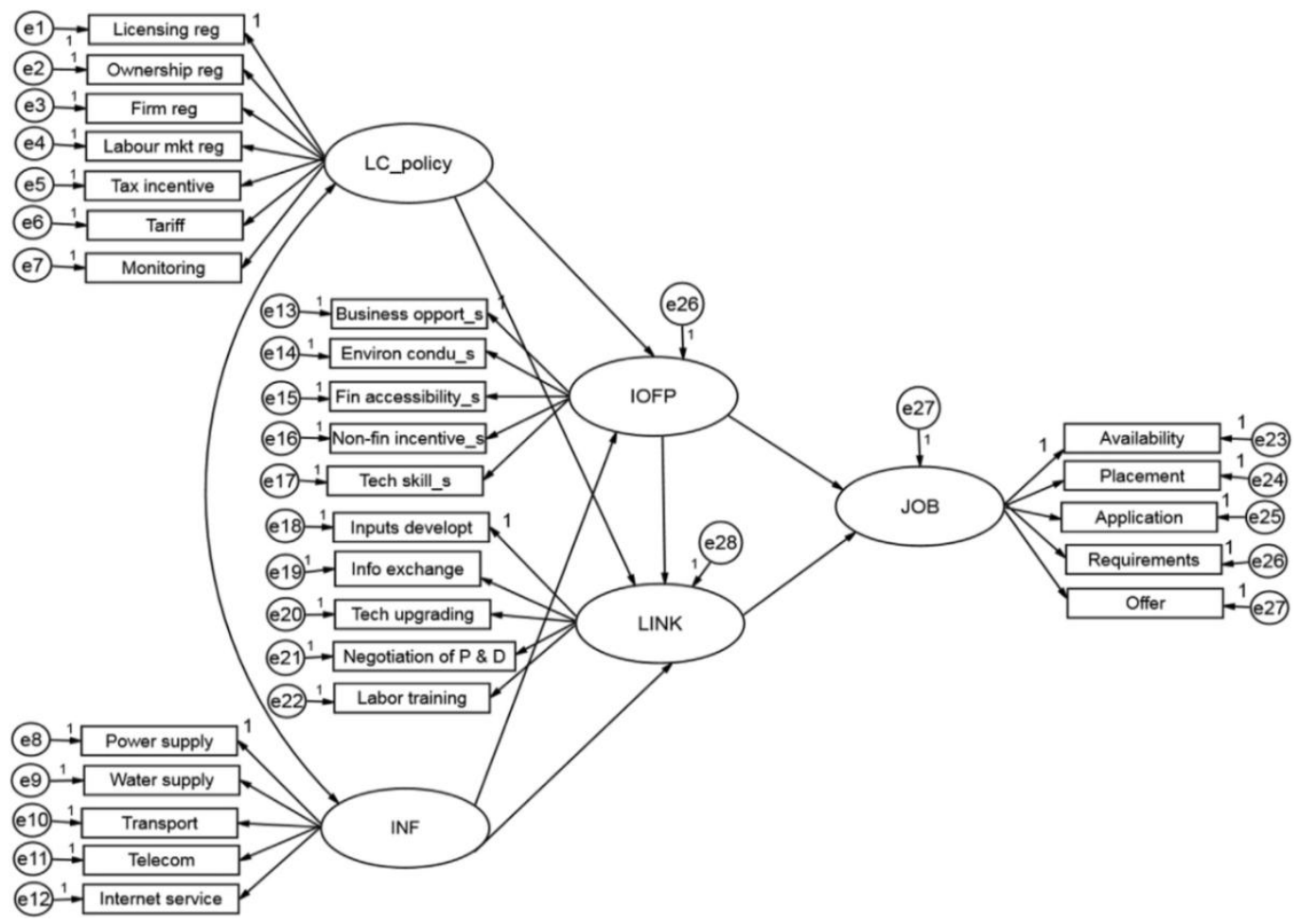

Sumber : (Adedeji et al., 2016)

Jurnal "PERFORMANCE" Bisnis \& Akuntansi Volume 8 No.1 Maret 2018 


\section{FAKULTAS EKONOMI DAN BISNIS UNIVERSITAS WIRARAJA SUMENEP - MADURA}

\section{Keuntungan dan Kelemahan}

Kelebihan SEM dibandingkan alat analisis lainnya yaitu SEM dapat menyelesaikan kasus dengan banyak variabel baik variabel eksogen maupun variabel endogen. Dalam SEM, baik variabel laten maupun variabel manivest bisa berfungsi sebagai variabel eksogen maupun endogen(Shah \& Goldstein, 2006). SEM juga dapat dipakai untuk menyelesaikan permasalahan dengan variabel laten yang tidak terukur secara langsung namun dapat diukur menggunakan kombinasi linier dari berbagai variabel yang dapat diamati. Keuntungan SEM dibandingkan metode statistik linear dalam parameter lainnya adalah sebagai berikut: pengobatan endogen dan eksogenvariabel sebagai variabel acak dengan kesalahan pengukuran, variabel laten dengan banyak indikator, pemisahan kesalahan pengukuran dari kesalahan spesifikasi, uji model secara keseluruhan dan bukan koefisien secara individual, pemodelan variabel mediasi, pemodelan hubungan kesalahan, pengujian koefisien pada beberapa kelompok dalam sampel, pemodelan fenomena dinamis seperti kebiasaan dan inersia, penghitungan data yang hilang, dan penanganan data tidak normal (Golob, 2001).

SEM merupakan alat analisis yang dapat dipakai untuk kasus kompleks. SEM adalah teknik statistik yang sangat powerful untuk menyelesaikan 1. Konfirmatory factor analysis (CFA), 2. Analisis regresi berganda model simultan, 3. Analisis regresi dengan masalah multikolinieritas, 4. Analisis path dengan multiple dependent, 5. Estimasi korelasi dan kovarian dalam model, dan 6. analisis jalur (Awang, 2014; Golob, 2001; Shah \& Goldstein, 2006).

Strukturnya yang kompleks membuat SEM mampu mengatasi masalah-masalah yang kompleks yang sulit diselesaikan oleh alat analisis lainnya. Penggunaan SEM dalam ilmu ekonomi mampu membantu menyelesaikan permasalah dalam penelitian ekonomi yang sering kali sangat kompleks . Namun karena struktur yang kompleks tersebut membuat SEM tidak mudah dipahami sehingga membutuhkan tingkat kehatihatian yang tinggi untuk melakukan interpretasi dari hasil analisisnya agar tidak terjadi kesalahan dalam kesimpulan. Seiring berjalannya waktu, terjadi banyak pro dan kontrak terhadap SEM. (Nachtigall et al., 2003).

\section{Meta-Analytic Structural Equation Modeling (MASEM)}

Dalam perkembanganya, lahir sebuah analisis baru yang merupakan meta analisis dari beberapa penelitian sejenis yang menggunakan SEM yaitu Meta-Analytic Structural Equation 
Modeling (MASEM). Meta-analytic structural equation modeling (MASEM) adalah analisis statistik yang menggabungkan dua metodologi penelitian yaitu Meta - analitik (MA) dan Structural equation modeling (SEM). MA adalah analisis statistik dari hasil analisis beberapa penelitian, yang bertujuan untuk mengintegrasikan temuan dalam bentuk effect size ((Budsankom, Sawangboon, \& Damrongpanit, 2015). MASEM menggunakan teknik sintesis matriks korelasi dan pengujian SEM. Meta analisis terhadap matrik korelasi yang menghasilkan matrik korelasi gabungan. Matrik korelasi gabungan dianalisis dengan SEM (Cheung \& Chan, 2005).

Analisis MASEM dilakukan dengan 2 langkah yaitu: Langkah 1; pencarian matriks korelasi gabungan terdiri dari tiga tahap; 1) transformasi Koefisien korelasi dalam standard normal metric menggunakan transformasi Fisher's r-to-Z sebelum menghitung bobot rata-rata dari nilai yang berubah dalam fixed-effects model.. 2) Selanjutnya, Uji homogenitas korelasi hasil transformasi dengan Hedges and Olkin's Q. Jika hasilnya tidak signifikan (tidak homogen) maka matriks korelasi gabungan dihitung menggunakan fixed-effects model, namun sebaliknya, jika hasil menunjukkan homogen, maka matriks korelasi gabungan dihitung menggunakan random-effects. 3) Bobot rata-rata korelasi di transformasi kembali menggunakan Fisher's Z-to-r untuk memudahkan interpretasi dalam pelaporan. Program komputer MetaAnalysis Comprehensive digunakan untuk melakukan analisis data. Langkah 2; Melakukan analisis SEM dari matriks korelasi gabungan dari effect. Kriteria kesesuaian model terdiri dari comparative fit index; $\mathrm{CFI}$, indeks Tucker - Lewis; TLI, Standardized root mean squared residual; SRMR, dan Root mean squared error of approximation; RMSEA. goodness of fit statistic dari validitas struktural menunjukkan bahwa model yang sangat baik adalah CFI dan TLI $\geq .95$ SRMR dan RMSEA $\leq .05$. Langkah-kangkah analisis yang harus dilakukan yaitu: 1. meta analysis dari effect size untuk menemukan arah dan besarnya hubungan antara dua variabel, meliputi korelasi Pearson (r) dan perbedaan standardized mean (g). 2 . membuat matriks korelasi gabungan dari effect size untuk menentukan effect size variabel, dan 3. melakukan analisis pada matriks korelasi gabungan dengan SEM (Budsankom et al., 2015).

Terdapat dua pendekatan utama yang menjadi landasan untuk MASEM, yaitu 1) Model analisis yang diusulkan oleh Viswesvaran dan Ones, biasanya diterapkan bila tidak ada penelitian yang 


\section{FAKULTAS EKONOMI DAN BISNIS UNIVERSITAS WIRARAJA - MADURA}

memberikan informasi lengkap dari semua variabel yang ada dalam model yang di hipotesiskan. 2) two-stage SEM (TSSEM), biasanya dipakai bila setidaknya ada satu studi yang memberikan informasi lengkap. Untuk metode yang pertama yang diusulkan oleh Viswesvaran dan Ones, sebagaimana analisis SEM, Analisis MASEM terdiri dari dua model yaitu measurement Model dan model kasual. Terdapat 5 langkah untuk pengujian teori dalam measurement Model yaitu 1) mengidentifikasi konstruk dan relasi yang penting, 2) mengidentifikasi pengukuran yang berbeda yang digunakan untuk mengoperasionalkan konstruks, 3) menunjukkan semua statistik yang berkaitan dan semua kepentingannya dalam studi, 4) memproses meta-analisis dan memperkirakan nilai sebenarnya dari hubungan pengukuran, 5) menggunakan analisis faktor untuk menguji measurement models. Untuk model kasual, terdiri dari 2 langkah yaitu : 6) memperkirakan nilai korelasi antara struktur dari struktur yang berbeda, dan 7) menggunakan analisis jalur dengan estimasi nilai korelasi yang benar untuk menguji teori yang diajukan (Budsankom et al., 2015).

Langkah-langkah analisis MASEM dengan metode TSSEM adalah langkah pertama, Persyaratan data yaitu Matriks korelasi atau kovarians dengan ukuran sampel yang sesuai diperlukan untuk setiap penelitian. Variabel yang hilang diizinkan; langkah kedua adalah Tahap 1 dari TSSEM: Pendekatan CFA multiple-group untuk menguji homogenitas matriks korelasi di seluruh penelitian. Matriks korelasi gabungan matriks $\mathrm{V}$ dan kovarian asimtotiknya dapat diperoleh pada tahap analisis ini. Jika homogenitas matriks korelasi tidak ditolak, kita bisa melanjutkan ke Tahap 2 TSSEM. Jika hipotesis homogenitas ditolak, moderator kategori potensial dapat digunakan untuk mengklasifikasikan penelitian ke dalam subkelompok homogen. Dan terakhir, langkah ketiga adalah Tahap 2 dari TSSEM: Matriks korelasi gabungan dan matriks kovariansi asimtotik digunakan sebagai masukan pada metode estimasi ADF. Ukuran sampel total (N) dari semua penelitian digunakan sebagai ukuran sampel untuk menyelesaikan model (Cheung \& Chan, 2005)

\section{Aplikasi SEM dalam ilmu ekonomi}

Contoh-contoh kasus yang menggunakan analisis SEM sebagai gambaran untuk mendalami SEM dikupas singkat dalam uraian berikut. Penelitian mengenai pengaruh kepuasan terhadap keluhan dan loyalitas yang berdasarkan harapan mahasiswa 
Gambar 4.

Kerangkah fikir loyalitas mahasiswa

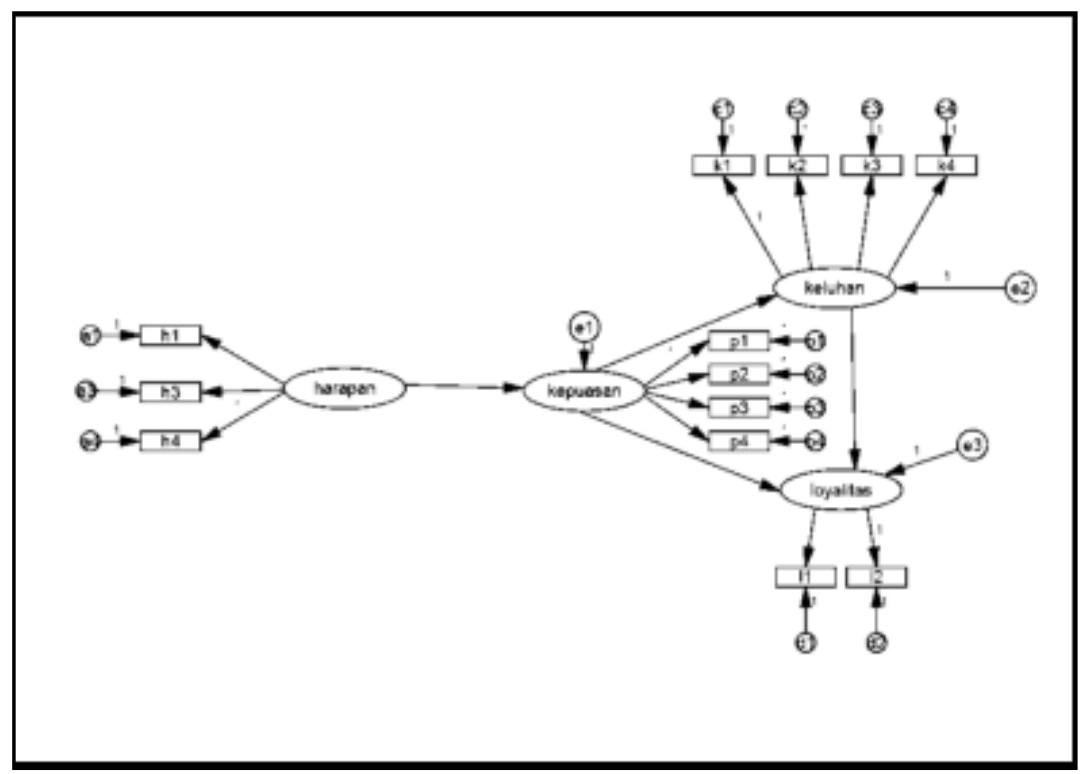

Sumber : (Sayyida, 2014)

perguruan tinggi swasta sebagaimana digambarkan dalam gambar 4 berikut memberikan kesimpulan bahwa harapan mahasiswa berpengaruh positif terhadap kepuasan, kepuasan berpengaruh negatif terhadap keluhan, sedangkan loyalitas dipengaruhi kepuasan secara positif dan dipengaruhi keluhan secara negatif. Artinya, mahasiswa akan loyal jika mereka puas dengan harapannya (Sayyida, 2014)

Penelitian yang dilakukan Alshetewi \& Karim, (2015) membentuk sebuah model yang disusun untuk menganalisis fakator-faktor yang mempengaruhi implementasi $\mathrm{T}$ Goverment (transformational government). T-Government adalah suatu pendekatan yang mempertimbangkan keseluruhan hubungan antara berbagai departemen pemerintah dan pengguna layanan publik. Faktor-faktor yang teridentifikasi dapat mempengaruhi T-Government antara lain strategi, kepemimpinan, pemangku kepentingan, pendanaan dan sentrisitas warga Negara seperti kerangka fikir pada gambar 5. Strategi dan peraturan diukur melalui: pentingnya strategi e-Government, rencana strategi, sasaran strategi, visi strategi, dan komitmen strategi. kepemimpinan diukur dengan: dukungan kepemimpinan, gaya kepemimpinan, dan pengaruh kepemimpinan yang kuat. pemangku kepentingan yang berpartisipasi diukur dengan: keterlibatan stakeholder, manajemen pemangku kepentingan, dan koordinasi pemangku kepentingan. Dana diukur melalui jumlah dana, mekanisme pengukuran, pengelolaan dana, dan 


\section{FAKULTAS EKONOMI DAN BISNIS UNIVERSITAS WIRARAJA - MADURA}

pengontrolan dana. Centricity warga diukur dengan legislasi sentris warga, pengukuran warga dan kepuasan warga. Survei menggunakan kuisioner dengan skala likert interval 6 terhadap 166 organisasi. Dari 917 kuisioner yang disebar hanya 217 yang lengkap dan dapat digunakan sebagai sampel. Langkah-langkah analisis yang dilakukan secara berturut-turut: 1 . statistik deskriptif untuk memberi gambaran data yang dianalisis, 2. Uji reliabilitas dengan cronbach's alpha untuk mengukur internal konsistensi. Dengan menggunakan kriteria Hair Jr, Black et.al., 2010 jika nilai cronbach's alpha diatas 0,7 maka dikatakan reliabel, 3. Uji validitas dengan melihat convergent validity (Average Variance extracted/ AVE > 0,5), constructs factor loading (significant loading > 0,5) dan diskriminant validity (AVE > square correlation dari konstruk., 4. Uji kecocokan model dengan RMSE, Chi- square, CFI, dan TLI, 5. Hasil pengujian hipotesis menggunakan nilai C.R pada Path Analysis. Langkah 2 dan 3 dimaksudkan untuk menguji measurement model sedangkan langkah 4 dan 5 untuk menguji structural model. Software SPSS digunakan untuk statistik deskriptif, uji reliabilitas dan uji validitas. Sedangkan untuk struktural model yaitu uji kecocokan model serta pengujian hipotesis diperoleh menggunkan software AMOS. Hasil penelitian menunjukkan bahwa ada hubungan positif dan signifikan antara strategi (stretegy) dan t-Government; pemangku kepentingan (stakeholders) dan t-government; serta kepemimpinan (leadership) dan t-government. Studi ini juga menunjukkan hubungan yang tidak signifikan antara sentrisitas warga negara (citizen's centricity) dan tGovernment serta pendanaan (funding) dan t-Government.

Gambar 5.

Kerangka pikir faktor-faktor yang mempengaruhi T-Goverment

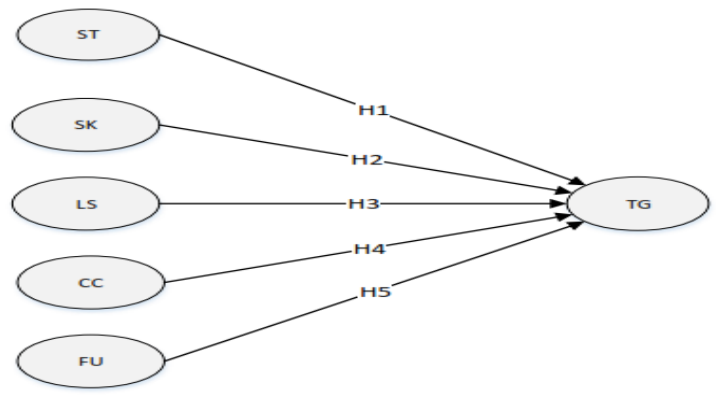

Sumber: (Alshetewi \& Karim, 2015) 
Gambar 6.

Kerangka pikir penelitian loyalitas pengunjung perpustakaan

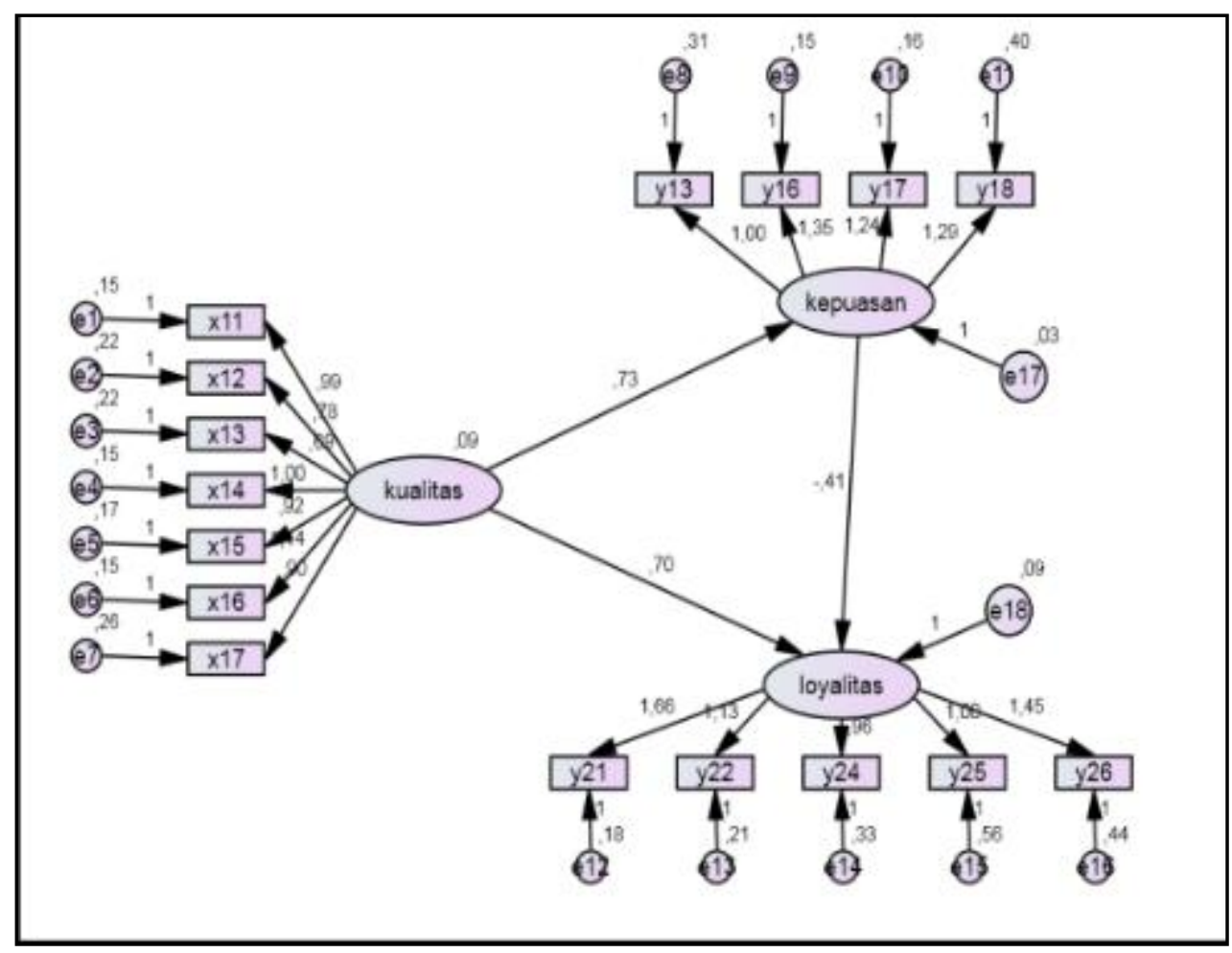

Sumber: (Sayyida, Hermanto, \& Sugianto, 2015)

SEM yang dipakai dalam menyelesaikan penelitian tentang loyalitas pengunjung perpustakaan daerah di Sumenep sebagaimana kerangka fikir pada gambar 6 berikut menggunakan sampel 200 pengunjung yang terdiri dari siswa, mahasiswa dan umum. Hasil menunjukkkan bahwa kualitas pelayanan berpengaruh positif terhadap kepuasan dan loyalitas pengunjung. Namun loyalitas pengunjung tidak dipengaruhi oleh kepuasan (Sayyida et al., 2015).

Penelitian

mengenai

ketertarikan mahasiswa terhadap kewirausahaan di wilayah Mid-Atlantic di Amerika Serikat sebagaimana kerangkah pikir pada gambar 7. Dengan menggunakan sampel 424 mahasiswa yang terdaftar di kursus bisnis divisi atas di sebuah institusi publik di wilayah Mid-Atlantic di Amerika Serikat. Motivasi afiliasi diukur dengan 26 item pertanyaan dengan skala pengukuran interval 5. Masing-masing variabel diukur dengan 3 sampai 4 indikator. Uji validiatas pengukuran menggunakan koefisien alpha. SEM dengan software AMOS digunakan untuk menguji kebaikan model pengukuran/ measurement model dan model struktural/structural model terhadap data serta untuk menguji hipotesis. Pengujian measurement model menggunakan 


\section{FAKULTAS EKONOMI DAN BISNIS UNIVERSITAS WIRARAJA - MADURA}

analisis faktor confirmatory (CFA) untuk menguji hubungan antara indikator dan respectasi dalam mengukur variabel laten. Uji structural model dimaksudkan untuk menguji hipotesis dan juga untuk menguji kebaikan model. Kebaikan model diuji menggunakan chi-square goodness-of-fit statistic, chi-square statistic/degrees of freedom, RMSEA dan CFI. Hasil penelitian menunjukkan dukungan emosional dan stimulasi yang positif berkontribusi terhadap ketertarikan mahasiswa dalam berwirausaha namun dengan arah yang berbeda. Dukungan emosional dan stimulus positif saling bertolak belakang dalam kontribusinya terhadap ketertarikan mahasiswa dalam berwirausaha. Jika dukungan emosional berkontribusi berlawanan arah sedangkan stimulus positif berkontribusi searah. Dan terbukti dua variabel lainnya yaitu perbandingan sosial dan attensi tidak signifikan berkontribusi terhadap ketertarikan mahasiswa dalam berwirausaha (Decker et al., 2012).

Gärling, T., \& Fujii, S. dalam penelitiannya yang berjudul Structural equation modeling of determinants of implementation intentions menggunakan 277 sampel yang selanjutnya diuji menggunakan SEM. Analisis faktor eksplorasi membantu peneliti untuk mengeksplorasi data dan memberikan informasi yang berkaitan dengan faktor- faktor yang dibutuhkan untuk mewakili data dengan sebaik-baiknya. Dalam kasus analisis faktor konfirmatori, peneliti menentukan jumlah faktor yang ada dalam sekumpulan variabel, dimana faktor yang masing-masing variabel akan muat tinggi sebelum hasilnya dihitung, dan statistik analisis faktor penyerta memberi tahu kita seberapa baik spesifikasi dari Faktor-faktor tersebut sesuai dengan data aktual. Pemodelan persamaan struktural (SEM) menggunakan AMOS digunakan untuk melakukan analisis faktor konfirmatori. Hasilnya seperti diagram dalam gambar 8 konsisten dengan dan memperluas temuan dalam beberapa penelitian terbaru yang menunjukkan bahwa mendorong niat implementasi meningkatkan kemungkinan perilaku dilakukan.(Gärling, 1999)

Studi mengenai dampak kebijakan LC (local content) dalam memengaruhi penciptaan nilai lokal dengan referensi khusus untuk partisipasi perusahaan minyak asli, hubungan balik dan penciptaan lapangan kerja telah dilakukan di Delta Niger. Sejumlah 209 perusahaan minyak dan gas bumi lokal menjadi sampel dalam studi ini. Analisis SEM digunakan untuk melihat hubungan kausal antara variabel laten eksogen dan endogen. Dilakukan 2 uji model yaitu measurement model (Gambar 2) dan struktural model 
(gambar 3). Dalam measurement model, diuji reliabilitas dari indikator yang dipakai untuk mengukur variabel laten. Struktural model dipakai untuk menguji hubungan antara variabel laten endogen dan eksogen. SEM juga bisa mendeteksi permasalahan multikolinieritas dan juga dapat memodifikasi hubungan yang mungkin. Software AMOS dengan metode estimasi ML. Digunakan metode estimasi ML karena dapat menghasilkan estimasi yang konsisten dalam kasus data yang tidak normal (Adedeji et al., 2016).

\section{Gambar 7.}

\section{Kerangka pikir ketertarikan mahasiswa terhadap kewirausahaan}

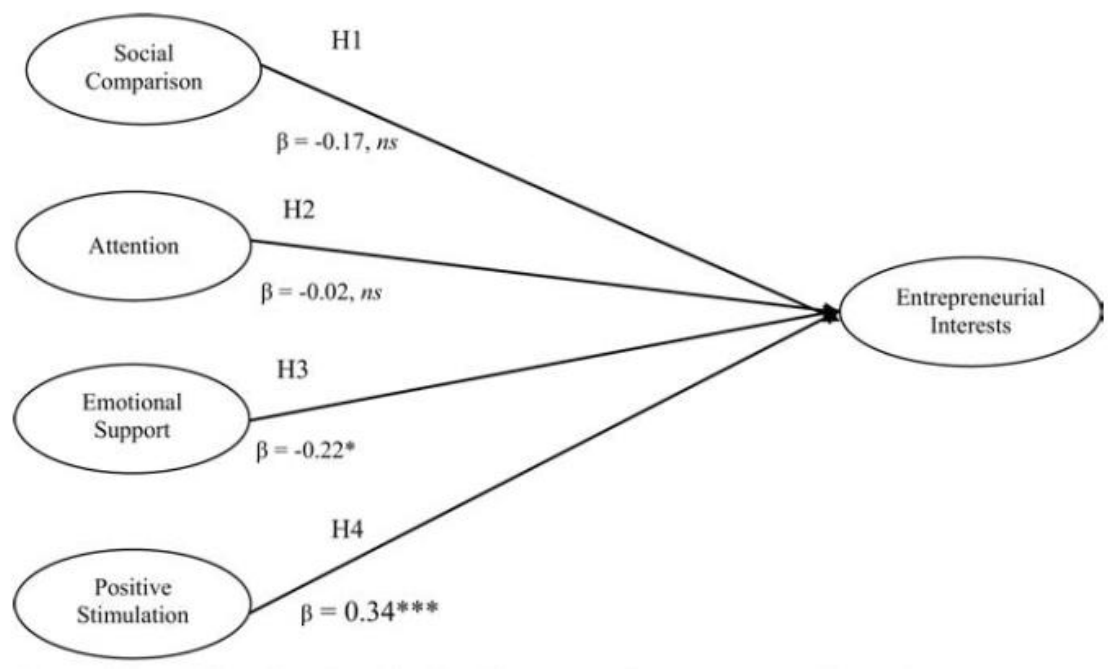

Sumber :(Decker et al., 2012)

Gambar 8.

Kerangka pikir implementasi dan perilaku

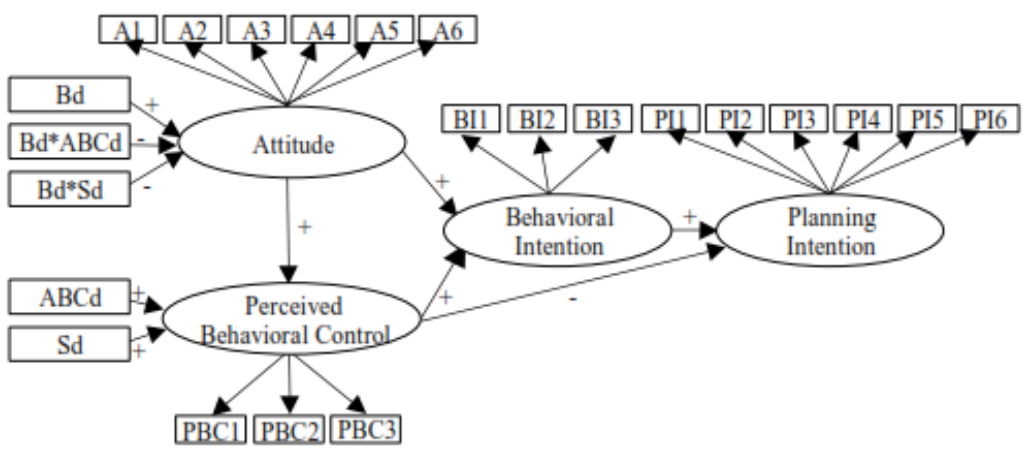

Sumber : (Gärling, 1999) 


\section{Gambar 9.}

Kerangka pikir kinerja keselamatan dan kesehatan

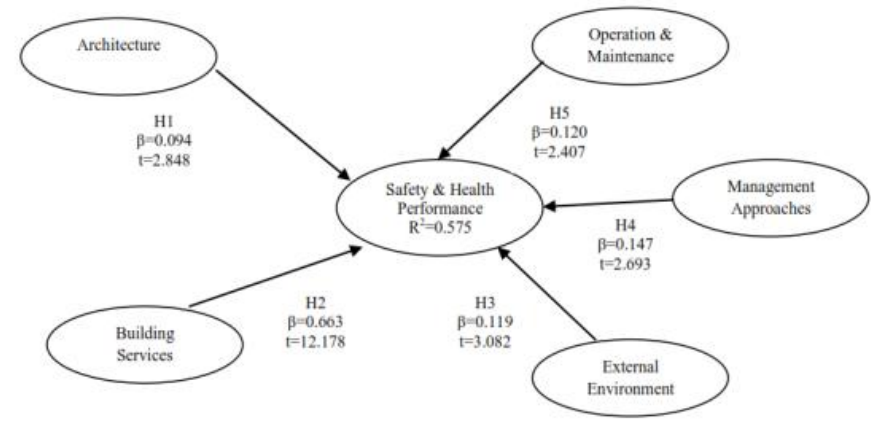

Sumber : (Ramli et al., 2014)

Penelitian yang bertujuan untuk mengukur kuantitatif tingkat kesesuaian dengan para praktisi konstruksi terhadap peningkatan kinerja keselamatan dan kesehatan perumahan murah di Malaysia (gambar 9). parsial least squares (PLS) dan pemodelan persamaan struktural (SEM) diusulkan untuk menguji secaraempirirs dari 268 paktisi konstruksi. Mengukur validasi dan pengujian model dilakukan dengan menggunakan software SmartPLS. Langkah-langkah nalisis data yang dilakukan pertama, model pengukuran digunakan untuk mengevaluasi dan mengembangkan reliabilitas dan validitas instrumen penelitian. Kedua, setelah penyesuaian item dan penerimaan model pengukuran, model struktural dievaluasi untuk menilai hubungan hipotesis antara konstruksi dalam model konseptual. Langkah selanjutnya adalah pengukuran model pengukuran dan model struktural yang menghasilkan outpur sebagaimana gambar berikut (Ramli et al., 2014)
.Penelitian lainnya terkait identifikasi variabel moderasi struktur desentralisasi dalam penyusunan anggaran yang dilakukan di SKPD Kabupaten Sumenep. Hasil analisis menunjukkan bahwa struktur desentralisasi tidak terbukti sebagai variabel moderator yang memoderasi hubungan partisipasi dalam penyusunan anggaran terhadap kinerja manajerial. Namun struktur desentralisasi ikut berpengaruh terhadap kinerja manajerial tersebut(Sayyida \& Anekawati, 2012)

\section{Kesimpulan}

Fenomena ekonomi yang kompleks membutuhkan suatu alat analisis yang mampu menyelesaikan struktur analisis yang komplek. Structural Equation Modeling (SEM) dengan strukturnya yang kompleks mampu mengatasi masalah-masalah yang kompleks yang sulit diselesaikan oleh alat analisis lainnya. Sehingga SEM sangat dan banyak digunakan dalam ilmu ekonomi. SEM pertama kali diperkenalkan pada tahun 1917 dan 
mulai berkembang di tahun 1970-an. SEM merupakan teknik analisis multivariat yang dibangun karena adanya keterbatasan teknik klasik yaitu Ordinary Least Square (OLS) khususnya dalam melakukan analisis dengan variabel laten dan model-model yang komplek. SEM adalah teknik statistik yang sangat powerful yang menggabungkan antara analisis path dan CFA yang bertujuan untuk mengkonfirmasi model yang sudah di hipotesiskan. Terdapat 2 model simulatan dalam SEM yaitu model pengukuran dan model struktural yang diperkirakan bersamaan. Metode estimasi SEM yang paling umum digunakan adalah: teori normal maximum likelihood (ML), general least least square (GLS), kuadrat terkecil tertimbang (WLS), dalam bentuk seperti distribusi berdimensi asimtotik bebas kuadrat terkecil (ADF atau ADF-WLS), dan kuadrat terkecil belakang elips (EGLS atau ELS). Software yang dapat dipakai untuk menyelasaikan SEM diantaranya AMOS, LISREL, EQS, Mplus, SmartPLS dan lain-lain. Kebanyakan software tersebut menggunakan metode estimasi Maksimum Likelihood (ML), dengan asumsi normal secara multivariat dan memliki ukuran sampel yang cukup besar.
Cara kerja SEM diawali dengan teori untuk membangun model yang akan dihipotesiskan. Kerangka pikir digambarkan dalam sebuah diagram yang menghubungkan antar variabel baik variabel laten maupun variabel manifest. Variabel laten biasanya diukur menggunakan kuisioner. Untuk menguji measurement model, diagram digambakan dengan hubungan 2 arah antar variabel laten. Measurement model bertujuan untuk menguji validitas dan reliabilitas indikator. Sedangkan untuk menguji struktural model, diagram digambarkan sesuai kerangka pikir yang telah dihipotesiskan. Struktural model bertujuan untuk menguji hipotesis dan juga fit model/ uji kesesuaian model. Uji kecocokan model bertujuan untuk mengkonfirmasi model dengan data empiris. Untuk mendapatkan estimasi yang akurat, SEM membutuhkan sampel besar yaitu lebih dari 100 sampel .

Dalam perkembanganya, lahir sebuah analisis baru yang merupakan meta analisis dari beberapa penelitian sejenis yang menggunakan SEM yaitu Meta-Analytic Structural Equation Modeling (MASEM). MASEM adalah analisis statistik yang merupakan gabungan antara Meta - analitik (MA) dan Structural equation modeling (SEM). Dua langkah analisis yaitu 1). pencarian matriks korelasi gabungan dengan transformasi Koefisien korelasi 


\section{FAKULTAS EKONOMI DAN BISNIS UNIVERSITAS WIRARAJA - MADURA}

dalam standard normal metric menggunakan transformasi Fisher's r-to$\mathrm{Z}$ sebelum menghitung bobot rata-rata dari nilai yang berubah dalam fixedeffects model, Uji homogenitas korelasi hasil transformasi dengan Hedges and Olkin's Q. Jika hasilnya tidak signifikan (tidak homogen) maka matriks korelasi gabungan dihitung menggunakan fixedeffects model, namun sebaliknya, jika hasil menunjukkan homogen, maka matriks korelasi gabungan dihitung menggunakan random-effects, selanjutnya mencari bobot rata-rata korelasi di transformasi kembali menggunakan Fisher's Z-to-r untuk memudahkan interpretasi dalam pelaporan. Program komputer MetaAnalysis Comprehensive digunakan untuk melakukan analisis data. 2) Melakukan analisis SEM dari matriks korelasi gabungan dari effect dengan uji kesesuaian mode berdasarkan comparative fit index; CFI, indeks Tucker - Lewis; TLI, SRMR, dan atau RMSEA

\section{DAFTAR PUSTAKA}

Adedeji, A. N., Sidique, S. F., Rahman, A. A., \& Law, S. H. (2016). The role of local content policy in local value creation in Nigeria's oil industry: A structural equation modeling (SEM) approach. Resources Policy, 49, 61-73. https://doi.org/10.1016/j.resour pol.2016.04.006
Alshetewi, S., \& Karim, F. (2015). A Structural Equation Model ( SEM ) of Governing Factors Influencing the Implementation of $\mathrm{T}$ Government, 6(11), 119-125.

Awang, Z. (2014). A Handbook on SEM for Academicians ang practitioners. Selangor: MPWS Rich Resources.

Budsankom, P., Sawangboon, T., \& Damrongpanit, S. (2015). Factors affecting higher order thinking skills of students: A meta-analytic structural equation modeling study, 10(19), 2639-2652. https://doi.org/10.5897/ERR20 15.

Cheung, M. W.-L., \& Chan, W. (2005). Meta-analytic structural equation modeling: A twostage approach. Psychological Methods, 10(1), 40-64. https://doi.org/10.1037/1082989X.10.1.40

Decker, W. H., Calo, T. J., Weer, C. H., Decker, W. H., Calo, T. J., \& Weer, C. H. (2012). careers Affiliation motivation and interest in entrepreneurial careers.

https://doi.org/10.1108/026839 41211205835

Gärling, T. (1999). Structural Equation Modeling of Determinants of Implementation Intentions.

Golob, T. F. (2001). Structural Equation Modeling for Travel Behavior Research.

Kusurkar, R. A., Vos, C. M. P., Westers, P., \& Croiset, G. (2013). How motivation affects academic performance : a structural equation modelling analysis, 57-69.

https://doi.org/10.1007/s10459 -012-9354-3 
Nachtigall, C., Kroehne, U., Funke, F., \& Steyer, R. (2003). ( Why ) Should We Use SEM? Pros and Cons of Structural Equation Modeling, 8(2), 122.

Ramli, A., Akasah, Z. A., \& Masirin, M. I. M. (2014). Safety and Health Factors Influencing Performance of Malaysian Low-cost Housing: Structural Equation Modeling (SEM) Approach. Procedia - Social and Behavioral Sciences, 129, 475-482.

https://doi.org/10.1016/j.sbspr o.2014.03.703

Sayyida, S. (2014). Harapan, Kepuasan Dan Keluhan Terhadap Loyalitas Mahasiswa Di Universitas Wiraraja Sumenep. Wacana Equilibrium, 2(1), 116.

Sayyida, S., \& Anekawati, A. (2012). Penggunaan Analisis Structural Equation Modelling (SEM) Dalam Mengidentikasi Pengaruh Variabel Moderasi Struktur Desentralisasi Terhadap Hubungan Partispasi Dalam Penyusunan Anggaran Dan Kinerja Manajerial SKPD Di Kabupaten Sumenep. Prosiding Univeritas Wiraraja, 1(1), 63-75.

Sayyida, S., Hermanto, B., \& Sugianto, E. (2015). Pentingnya Kualitas Pelayanan Terhadap Kepuasan Dan Loyalitas Pengunjung Perpustakaan Daerah Kabupaten Sumenep. Performance: Jurnal Bisnis \& Akuntansi, 5(2), 67-79.
Shah, R., \& Goldstein, S. M. (2006). Use of structural equation modeling in operations management research : Looking back and forward §, 24 , $148-169$. https://doi.org/10.1016/j.jom.2 005.05.001 